\title{
Survei Kondisi Fisik Peserta Kegiatan Ekstrakurikuler Bolabasket
}

\author{
Andreano Febrio Valentino ${ }^{1 *}$, Siti Nurrochmah ${ }^{2}$ \\ 1,2Jurusan Pendidikan Jasmani, Kesehatan dan Rekreasi, Fakultas IImu Keolahragaan, \\ Universitas Negeri Malang, Jalan Semarang No 5, Malang, Jawa Timur, 65145, Indonesia \\ *Penulis koresponden: febrival05@gmail.com, 082222205431
}

Artikel diterima: 7 Januari 2020; direvisi: 16 Oktober 2020; disetujui: 22 Oktober 2020

\begin{abstract}
The purpose of this study was to determine the ability of the physical condition of the male and female groups participating in basketball extracurricular activities at the Santo Albertus High School, Malang City. The research design used a survey design. The results of the research on the chest pass medicine ball test and the vertical jump test for the male group were in the moderate category, the 20-meter running test, the Illinois test, and the vertical jump test for the female group were in the moderate and poor category. Conclusion from the research results there are still tests that have below good criteria.
\end{abstract}

Keyword: extracurricular activities, physical condition, basketball

\begin{abstract}
Abstrak: Tujuan penelitian ini yaitu untuk mengetahui kemampuan kondisi fisik kelompok putra dan putri peserta kegiatan ekstrakurikuler bolabasket di SMAK Santo Albertus Kota Malang. Rancangan penelitian menggunakan rancangan survei. Hasil penelitian pada tes chest pass bola medicine dan tes vertical jump untuk kelompok putra termasuk dalam kategori cukup, pada jenis tes lari 20 meter, tes illinois, dan tes vertical jump untuk kelompok putri termasuk dalam kategori cukup dan kurang baik. Simpulan dari hasil penelitian masih ada tes yang mempunyai kriteria dibawah baik.
\end{abstract}

Kata kunci: ekstrakurikuler, kondisi fisik, bolabasket

\section{PENDAHULUAN}

Olahraga merupakan salah satu aspek yang berperan besar dalam kehidupan manusia. Berdasarkan hasil penelitian dibeberapa banyak Negara termasuk di Indonesia, ternyata banyak mereka yang aktif melakukan kegiatan olahraga atau melakukan aktivitas dan latihan kebugaran jasmani, tidak mudah terkena penyakit. Namun faktanya masih banyak masyarakat yang meninggal dunia karena tidak rutin untuk melakukan aktivitas olahraga, perubahan jenis olahraga dari olahraga yang menjadi kebiasaannya atau sering dilakukan, beban olahraga yang terlalu berat, dan berat badan. Hal ini membuat kondisi fisik menjadi tidak seimbang. Karena kondisi fisik setiap orang berbeda, jenis olahraga yang dilakukannyapun juga berbeda. Olahraga yang dilakukan seseorang harus terukur dan teratur, bukan asal berkeringat.

Pendidikan Jasmani adalah sebuah proses pendidikan melalui pengalaman belajar kepada siswa berupa kegiatan jasmani, bermain dan aktivitas berolahraga yang direncanakan secara sistematik dan terprogram guna merangsang perkembangan fisik dan pertumbuhan, keterampilan berfikir, gerak, dan emosional. 
Peraturan Menteri No.62 tahun 2014 "Kegiatan ekstrakurikuler adalah kegiatan kurikuler yang dilakukan oleh peserta didik diluar jam belajar kegiatan intrakurikuler dan kegiatan kokurikuler, dibawah bimbingan dan pengawasan satuan pendidikan".

Di sekolah SMAK Santo Albertus Kota Malang kegiatan ekstrakurikuler mencangkup tentang seni kebudayaan dan olahraga bolabasket, bola voli, futsal, bulutangkis. Diantara sajian kegiatan olahraga tersebut, penulis tertarik mengkaji tentang jenis kegiatan kondisi fisik peserta kegiatan ekstrakurikuler bolabasket di SMAK Santo Albertus Kota Malang.

Dalam bidang olahraga, kegiatan ekstrakurikuler merupakan salah satu upaya dalam pembinaan bagi siswa yang pada tahap selanjutnya akan selalu ditingkatkan dengan berbagai bentuk-bentuk latihan khusus serta latihan uji coba atau latihan pertandingan antar pelajar, sesuai dengan tingkat pendidikan. Hal ini sangat penting agar pembinaan olahraga dikalangan pelajar terus meningkat sejalan dengan harapan dalam mencapai suatu tujuan yang maksimal.

Berdasarkan penelitian terdahulu yang pernah dilakukan oleh Hakim (2017) meneliti tentang masalah "Survei Kondisi Fisik Bagi Siswa Ekstrakurikuler Futsal MA AL MA'ARIF Singosari", penelitian lain yang dilakukan oleh Erwanto (2018) meneliti tentang masalah "Survei Kondisi Fisik Siswa Pencak Silat Persaudaraan Setia Hati Terate Ranting Tarokan Cabang Kediri”.

Berdasarkan latar belakang yang telah dipaparkan, ada ketertarikan Penulis melakukan suatu penelitian untuk mengetahui dan membahas lebih lanjut tentang "Survei Kondisi Fisik Peserta Ekstrakurikuler Bolabasket Di SMAK Santo Albertus Kota Malang".

Tujuan penelitian ini adalah mengetahui kemampuan kondisi fisik unsur kelincahan gerak, kecepatan gerak, dan daya ledak otot pada kelompok putra dan putri peserta kegiatan ekstrakurikuler bolabasket di SMAK Santo Albertus Kota Malang.

\section{METODE}

Penelitian ini termasuk penelitian deskriptif. Penelitian deskriptif bertujuan untuk mendeskripsikan (memaparkan) peristiwa yang terjadi masa kini. Deskripsi peristiwa tersebut dilakukan secara sistematik yang menekankan pada pengungkapan data berdasarkan fakta yang diperoleh dari lapangan (Jamshed, 2014). Variabel yang diteliti berupa survei kondisi fisik peserta ekstrakurikuler bolabasket di SMAK Santo Albertus Kota Malang.

Populasi dalam penelitian ini berjumlah 143 orang peserta sedangkan sampel yang digunakan 62 orang peserta dengan jumlah kelompok putra 44 orang peserta dan kelompok putri 18 orang peserta. Tes yang digunakan berupa tes lari 20 meter, tes $t$-test, tes illinois, tes chest pass bola medicine. Instrumen non tes yang digunakan di dalam penelitian ini yaitu berupa observasi (pengamatan) unjuk kerja tentang pelaksanaan tes lari sprint $20 \mathrm{~m}$, tes kelincahan T-Drill, llinois, dan tes daya ledak Vertical Jump.

Teknik analisis data yang diperoleh dari tes lari sprint $20 \mathrm{~m}$, tes kelincahan T-Drill, Ilinois, dan tes daya ledak Vertical Jump berupa data rasio, maka teknik analisis data penelitian yang digunakan untuk mengungkap tentang keadaan kondisi fisik peserta ekstrakurikuler bolabasket di SMAK Santo Albertus Kota Malang adalah statistika deskriptif. Teknik analisis statistika deskriptif kuantitatif yang digunakan dalam penelitian ini berupa skor maksimum, skor minimum, modus, rata-rata hitung (mean), standart deviasi, varian, koefisien variansi (KV). Pengelolaan data dilakukan secara manual dengan bantuan kalkulator Casio FX 3900 PV.

\section{HASIL}

Sajian pada analisis data tes lari 20 meter untuk kelompok putra pada peserta kegiatan ekstrakurikuler bolabasket di SMAK Santo Albertus Kota Malang yang berjumlah 44 orang peserta mendapatkan hasil baik sekali jika nilai kurang dari 2,86 dan mempunyai persentase $9,09 \%$, dinyatakan baik jika nilai yang muncul mempunyai rentang nilai 3,29 sampai 3,70 dengan persentase $43,18 \%$, nilai cukup mempunyai rentang nilai 3,71 sampai 4,12 dengan persentase $36,36 \%$, kurang baik jika rentang nilai 4,13 sampai 4,54 yang mempunyai persentase $9,09 \%$, dan tidak baik jika nilai yang muncul 4,55 sampai 4,96 dengan persentase $2,27 \%$. 
Pada analisis data tes $t$-test untuk kelompok putra pada peserta kegiatan ekstrakurikuler bolabasket di SMAK Santo Albertus Kota Malang yang berjumlah 44 orang peserta mendapatkan hasil baik sekali jika nilai kurang dari 10,26 dan mempunyai prosentase $9,09 \%$, dinyatakan baik jika nilai yang muncul mempunyai rentang nilai 12,18 sampai $14,09(47,73 \%)$, nilai cukup mempunyai rentang nilai 14,10 sampai $16,02(27,27 \%)$, kurang baik jika rentang nilai 16,03 sampai 17,95 (11,36\%), dan tidak baik jika nilai yang muncul 17,96 sampai 19,88 (4,55\%).

Data tes Illinois kelompok putra pada peserta kegiatan ekstrakurikuler bolabasket di SMAK Santo Albertus Kota Malang yang berjumlah 44 orang peserta mendapatkan hasil baik sekali jika nilai kurang dari 18,42 $(15,91 \%)$, dinyatakan baik jika nilai yang muncul mempunyai rentang nilai 20,07 sampai $21,72(38,64 \%)$, nilai cukup mempunyai rentang nilai 21,72 sampai $23,37(31,82 \%)$, kurang baik jika rentang nilai 23,38 sampai $25,02(6,82 \%)$, dan tidak baik jika nilai yang muncul 25,03 sampai $26,67(6,82 \%)$.

Analisis data tes chest pass bola medicine kelompok putra pada peserta ekstrakurikuler bolabasket di SMAK Santo Albertus Kota Malang yang berjumlah 44 orang peserta mendapatkan hasil tidak baik jika nilai kurang dari 4,48 dan (15,91\%), dinyatakan kurang baik jika nilai yang muncul mempunyai rentang nilai 5,01 sampai $5,53(34,09 \%)$, nilai cukup mempunyai rentang nilai 5,54 sampai $6,06(47,73 \%)$, baik jika rentang nilai 6,07 sampai 6,59 yang $(6,82 \%)$, dan baik sekali jika nilai yang muncul 6,60 sampai $7,12(6,82 \%)$.

Pada analisis data tes vertical jump untuk kelompok putra pada peserta ekstrakurikuler bolabasket di SMAK Santo Albertus Kota Malang yang berjumlah 44 orang peserta mendapatkan hasil tidak baik jika nilai kurang dari 226 dan mempunyai prosentase $(4,55 \%)$, dinyatakan kurang baik jika nilai yang muncul mempunyai rentang nilai 240 sampai (253 6,82\%), nilai cukup mempunyai rentang nilai 254 sampai 267 (40,91\%), baik jika rentang nilai 268 sampai 280 yang $(31,82 \%)$, dan baik sekali jika nilai yang muncul 281 sampai 293 (15,91\%).

Analisis data tes lari 20 meter untuk kelompok putri pada peserta kegiatan ekstrakurikuler bolabasket di SMAK Santo Albertus Kota Malang yang berjumlah 18 orang peserta mendapatkan hasil baik sekali jika nilai kurang dari $3,71(11,11 \%)$, dinyatakan baik jika nilai yang muncul mempunyai rentang nilai 4,06 sampai 4,40 $(27,78 \%)$, nilai cukup mempunyai rentang nilai 4,41 sampai $4,76(44,44 \%)$, kurang baik jika rentang nilai 4,77 sampai 5,11 yang $(16,67 \%)$.

Sajian pada analisis data tes $t$-test untuk kelompok putri pada peserta kegiatan ekstrakurikuler bolabasket di SMAK Santo Albertus Kota Malang yang berjumlah 18 orang peserta mendapatkan hasil baik sekali jika nilai kurang dari $8,64(22,22 \%)$, dinyatakan baik jika nilai yang muncul mempunyai rentang nilai 11,39 sampai 14,12 $(33,33 \%)$, nilai cukup mempunyai rentang nilai 14,13 sampai $16,86(27,78 \%)$, dan kurang baik jika rentang nilai 16,87 sampai $19,60(16,67 \%)$.

Data tes Illinois untuk kelompok putri pada peserta kegiatan ekstrakurikuler bolabasket di SMAK Santo Albertus Kota Malang yang berjumlah 18 orang peserta mendapatkan hasil baik sekali jika nilai kurang dari $<21,71(22,22 \%)$, dinyatakan baik jika nilai yang muncul mempunyai rentang nilai 23,72 sampai 25,72 $(27,78 \%)$, nilai cukup mempunyai rentang nilai 25,73 sampai $27,73(33,33 \%)$, kurang baik jika rentang nilai 27,74 sampai 29,74 (11,11\%), dan tidak baik jika nilai yang muncul 29,75 sampai $31,75(5,56 \%)$.

Pada analisis data tes chest pass bola medicine untuk kelompok putri pada peserta ekstrakurikuler bolabasket di SMAK Santo Albertus Kota Malang yang berjumlah 18 orang peserta mendapatkan hasil tidak baik jika nilai kurang dari 2,34 22,22\%, dinyatakan kurang baik jika nilai yang muncul mempunyai rentang nilai 2,67 sampai $2,9922,22 \%$, nilai cukup mempunyai rentang nilai 3,00 sampai $3,3138,89 \%$, baik jika rentang nilai 3,32 sampai 3,63 yang $11,11 \%$, dan baik sekali jika nilai yang muncul 3,64 sampai $3,955,56 \%$.

Sajian pada analisis data tes vertical jump untuk kelompok putri pada peserta kegiatan ekstrakurikuler bolabasket di SMAK Santo Albertus Kota Malang yang berjumlah 18 orang peserta mendapatkan hasil tidak baik jika nilai kurang dari $210(5,56 \%)$, dinyatakan kurang baik jika nilai yang muncul mempunyai rentang nilai 223 sampai 235 (50,00\%), nilai cukup mempunyai rentang nilai 236 sampai 249 (33,33\%), baik jika rentang nilai 250 sampai 262 (5,56\%), dan baik sekali jika nilai yang muncul 263 sampai 275 (5,56\%). 


\section{PEMBAHASAN}

Olahraga merupakan salah satu fungsi utama yang digunakan untuk menjaga kondisi fisik seseorang. Praviti, dkk (2013:32) berpendapat bahwa dimana kondisi fisik setelah diberikan latihan aktivitas olahraga lebih baik dibandingkan sebelum diberikan aktivitas olahraga. Kesimpulannya adalah aktivitas olahraga berpengaruh terhadap Dalam bidang olahraga khususnya olahraga bolabasket memerlukan beberapa unsur kondisi fisik yang harus dimiliki yaitu diantaranya terdapat kecepatan gerak, kelincahan gerak, daya ledak otot lengan dan daya ledak otot tungkai. Kecepatan gerak dalam permainan bolabasket juga diperlukan, kecepatan adalah salah satu komponen dasar oleh setiap cabang olahraga baik yang bersifat perlombaan maupun pertandingan, untuk itu kecepatan merupakan salah satu unsur biomotorik yang harus dilatihkan dalam upaya pencapaian prestasi atlet. Calleja-González et al. (2016) berpendapat bahwa permainan bolabasket memerlukan gerakan yang cepat untuk gerakan maju, mundur, lateral, dan gerakan diagonal. Olahraga bolabasket juga diperlukan untuk meraih keberhasilan dalam proses pengambilan bola (Trojian et al., 2013).

Ketika bermain bolabasket pemain bolabasket juga memerlukan daya ledak otot lengan dan daya ledak otot tungkai. Gołaś, Maszczyk, Zajac, Mikołajec, \& Stastny (2016) berpendapat bahwa daya ledak otot merupakan gabungan antara kekuatan dan kecepatan maksimal. Chaalali et al. (2016) berpendapat agility atau kelincahan adalah seperangkat keterampilan yang dilakukan oleh seseorang untuk merepons stimulus eksternal dengan perubahan arah dan gerakan perlambatan.

Daya ledak merupakan faktor utama untuk mengatasi beban pemain dalam hal ketika pemain bolabasket melakukan gerakan dengan kecepatan yang tinggi dan kelincahan gerak yang baik. Dengan menambah kekuatan otot untuk meningkatkan kecepatan serta daya ledak Chu \& Myer (2013:181) menyatakan bahwa latihan yang dapat meningkatkan daya ledak otot lengan dengan menggunakan latihan pliometrik chestpass bola medicine.

Sesuai dengan rumusan masalah yaitu bagaimana kemampuan kondisi fisik unsur kelincahan gerak, kecepatan gerak, dan daya ledak otot pada kelompok putra peserta kegiatan ekstrakurikuler bolabasket di SMAK Santo Albertus Kota Malang dan bagaimana kemampuan kondisi fisik unsur kelincahan gerak, kecepatan gerak, dan daya ledak otot pada kelompok putri peserta kegiatan ekstrakurikuler bolabasket di SMAK Santo Albertus Kota Malang, maka untuk memecahkan masalah tersebut peneliti telah melakukan analisis data menggunakan teknik statistika deskriptif yang meliputi tes lari 20 meter, tes $t$-test, tes illinois, tes chest pass bola medicine, tes vertical jump.

Data yang telah diperoleh selanjutnya dianalisis sesuai dengan teknik yang ditetapkan, sehingga hasil analisis telah diperoleh dan disajikan pada halaman terdahulu yaitu pada sub bab deskripsi data dan analisis data. Smith-Laing (2017) berpendapat bahwa perbedaan gender adalah salah satu pembeda kelompok berdasarkan jenis kelamin karena dalam hal ini perbedaan jenis kelamin merupakan factor anatomi, biomekanika, dan kemampuan kinerja dalam sebuah aktivitas gerak. Maka dari itu berdasarkan hasil analisis data, berikut akan disajikan pembahasan hasil penelitian yang merujuk pada rumusan masalah dan hasil analisis data dari kelompok putra dan putri peserta kegiatan ekstrakurikuler bolabasket di SMAK Santo Albertus Kota Malang. Adapun pembahasan akan dimulai dari:

\section{Kelompok Putra Peserta Kegiatan Ekstrakurikuler Bolabasket di SMAK Santo Albertus Kota Malang}

Secara keseluruhan dari hasil analisis tes lari 20 meter pada kelompok putra yang termasuk pada kriteria baik sampai baik sekali yaitu terdapat 23 orang peserta $(52,27 \%)$ dari 44 orang peserta dikarenakan peserta ekstrakurikuler bolabasket di SMAK Santo Albertus Kota Malang melakukan latihan lari sprint dengan rutin. Sarmento et al. (2018) menyatakan bahwa model latihan yang tepat untuk menambah kecepatan gerak dalam berlari adalah dengan metode repetisi melalui latihan sprint dengan beban.

Sedangkan yang berada dibawah cukup sampai tidak baik berjumlah 21 orang peserta $(47,73 \%)$ dari 44 orang peserta dikarenakan tidak memiliki energi yang cukup. Capelli, Pivetta, Esposito, \& Arber (2017) berpendapat bahwa untuk mengembangkan kecepatan gerak pemain harus memahami faktor yang mempengaruhi kemampuan kecepatan gerak. Salah satu faktornya adalah sistem energi yang dimiliki pada seseorang atau atlet. Dengan memiliki kecepatan yang baik, maka sebuah gerakan lari cepat atau sprint dalam permainan bolabasket akan menjadi baik.

Dari paparan hasil analisis data tes $t$-test pada kelompok putra yang termasuk pada kriteria baik sampai baik sekali yaitu terdapat 25 orang peserta $(56,82 \%)$ dari 44 orang peserta, sedangkan yang berada dibawah cukup 
sampai tidak baik berjumlah 19 orang peserta $(43,18 \%)$ dari 44 orang peserta. Dalam hal ini pserta ekstrakurikuler bolabasket membutuhkan unsur kelincahan gerak dan unsur kelincahan gerak dapat dilatih dengan latihan rope jump (Finco, Rocha, Fão, \& Santos, 2018).

Kondisi fiisk merupakan kemampuan tubuh untuk melakukan suatu pekerjaan atau aktivitas gerak olahraga yang akan dikerjakan sehari-hari tanpa menimbulkan efek kelelahan (Arhant, Wogritsch, \& Troxler, 2015). Hasil analisis data tes illinois pada kelompok putra yang termasuk pada kriteria baik sampai baik sekali yaitu terdapat 24 orang peserta $(54,55 \%)$ dari 44 orang peserta, kesimpulannya adalah dari 24 orang peserta yang mendapatkan kriteria baik sampai baik sekali untuk jenis tes illinois mempunyai kondisi fisik yang baik, sedangkan yang berada dibawah cukup sampai tidak baik berju mlah 20 orang peserta (45,45\%) dari 44 orang peserta belum memiliki kondisi yang baik dikarenakan kurangnya latihan unsur kelincahan gerak. Ariffiansyah (2019) berpendapat bahwa kelincahan gerak merupakan suatu bentuk gerakan yang mengharuskan seseorang atau pemain untuk bergerak secara cepat.

Untuk hasil analisis tes chest pass bola medicine pada kelompok putra yang termasuk pada kriteria baik sampai baik sekali yaitu terdapat 6 orang peserta (13,64\%) dari 44 orang peserta. Dari hasil analilis dapat dijelaskan bahwasannya dari 6 orang perserta yang mendapatkan kriteria baik sampai baik sekali aktif dalam melakukan olahraga yang berhubungan dengan kekuatan otot lengan.

Daya ledak otot lengan dapat didefinisikan sebagai gaya maksimal yang dapat dihasilkan oleh kumpulan otototot yang berada di seluruh bagian lengan (Conforto, Amaral, da Silva, Di Felippo, \& Kamikawachi, 2016), sedangkan yang berada dibawah cukup sampai tidak baik berjumlah 38 orang peserta $(86,36 \%)$ dari 44 orang peserta dikarenakan kurangnya latihan pushup atau pullup untuk menghasilkan kekuatan pada otot lengan. Pendapat (Meylan, Cronin, Oliver, Hopkins, \& Contreras (2014) daya ledak otot atau power adalah kemampuan otot untuk melakukan gerakan dengan intensitas yang lebih tinggi dan beban yang berat.

Sedangkan untuk hasil analisis data dari tes vertical jump pada kelompok putra yang termasuk pada kriteria baik sampai baik sekali yaitu terdapat 5 orang peserta $(11,36 \%)$ dari 44 orang peserta, dikarenakan dalam kelompok yang mendapatkan kriteria baik sampai baik sekali rutin melakukan gerakan olahraga yang berhubungan dengan kekuatan otot tungkai. Henjilito (2017)berpendapat bahwa daya ledak otot tungkai menghasilkan lompatan yang tinggi dalam cabang permainan bolabasket, sedangkan yang berada dibawah cukup sampai tidak baik berjumlah 39 orang peserta $(88,64 \%)$ dari 44 orang peserta dikarenakan kurangnya kekuatan otot tungkai saat melakukan loncatan. Paradisis et al. (2014) berpendapat bahwa daya ledak merupakan salah satu dari beberapa komponen kondisi fisik yang bersifat eksplosif, semakin tinggi loncatan akan, maka otot kaki akan semakin kuat.

Tabel 1. Koefesien Variansi Seluruh Butir Tes Kelompok Putra Peserta Kegiatan Ektrakurikuler Bolabasket di SMAK Santo Albertus Kota Malang

\begin{tabular}{llll}
\hline \multirow{2}{*}{ No } & Unsur Kondisi & Jenis Tes & \multirow{2}{*}{ KV (\%) } \\
\hline 1. & Kisik & Lari 20 Meter & 11,32 \\
2. & Kelincahan Gerak & Tes T-Test & 13,61 \\
& & Tes Illinois & 7,61 \\
3. & Daya Ledak Otot Lengan & Tes Chest Pass Bola & 9,54 \\
4. & Daya Ledak Otot Tungkai & Medicine & 5,46 \\
\hline
\end{tabular}

Berdasarkan koefesien variansi seluruh butir tes kelompok putra peserta kegiatan ekstrakurikuler bolabasket di SMAK Santo Albertus Kota Malang mendapatkan hasil tes vertical jump menunjukan lebih memusat dibandingkan butir tes lainnya, artinya pada tes vertical jump banyak siswa yang mempunyai skor mendekati baik atau sama antar individu. Sedangkan hasil tes kelincahan bentuk $t$-test, koefesien variansi diperoleh $13,61 \%$, berarti butir tes kelincahan gerak bentuk $t$-test lebih menyebar atau beragam artinya pada tes tersebut antar individu memperoleh nilai yang sangat bervariasi.

Berikut keadaan koefesien variansi seluruh butir tes pada kelompok putra akan disajikan dalam bentuk grafik. 


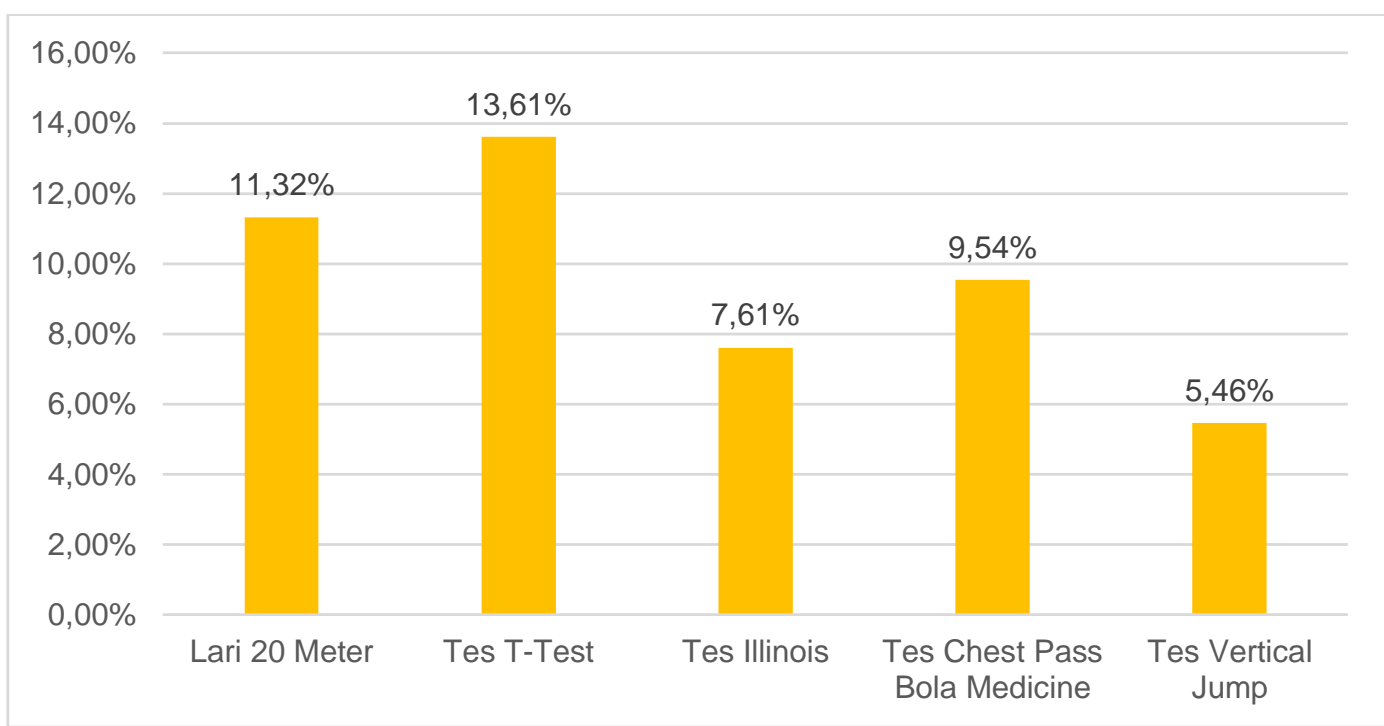

Gambar 1. Grafik Penyebaran Hasil Koefesien Variansi Pada Kelompok Putra Peserta Kegiatan Ekstrakurikuler Bolabasket di SMAK Santo Albertus Kota Malang

\section{Kelompok Putri Peserta Kegiatan Ekstrakurikuler Bolabasket di SMAK Santo Albertus Kota Malang}

Secara keseluruhan dari hasil analisis tes lari 20 meter pada kelompok putri yang termasuk pada kriteria baik sampai baik sekali yaitu terdapat 7 orang peserta $(38,89 \%)$ dari 18 orang peserta dikarenakan peserta ekstrakurikuler bolabasket di SMAK Santo Albertus Kota Malang untuk kelompok putri melakukan latihan kecepatan dengan lari cepat dalam garis lurus. Kecepatan merupakan kemampuan seseorang untuk menempuh jarak dengan cepat dengan tenaga yang semaksimal mungkin (Horicka, Hianik, \& Šimonek, 2014). Sedangkan yang berada dibawah cukup sampai tidak baik berjumlah 11 orang peserta $(61,11 \%)$ dari 18 orang peserta. Itulah sebabnya latihan kecepatan gerak harus diperhitungkan dengan tepat. Horicka, Hianik, \& Šimonek (2014) berpendapat bahwa ada beberapa prinsip tentang latihan kecepatan, yaitu: (1) suatu jarak yang dekat, (2) kecepatan yang maksimal, (3) jumlah repetisi, dan (4) istirahat yang cukup dan teratur.

Dari paparan hasil analisis data tes $t$-test pada kelompok putri yang termasuk pada kriteria baik sampai baik sekali yaitu terdapat 10 orang peserta $(55,56 \%)$ dari 18 orang peserta dikarenakan kondisi fisik mereka baik. Kondisi fisik adalah kemampuan tubuh untuk melakukan adaptasi terhadap gerakan fisik khususnya dalam kelincahan gerak (Kendzierski \& DeCarlo, 2016), sedangkan yang berada dibawah cukup sampai tidak baik berjumlah 8 orang peserta $(44,44 \%)$ dari 18 orang peserta dikarenakan kondisi fisik yang kurang maksimal. Salvagioni et al. (2017) berpendapat bahwa kondisi fisik yang kurang perlu untuk ditingkatkan dengan melakukan latihan secara sistematis dengan mengacu pada program latihan dan prinsip-prinsip latihan.

Hasil analisis data tes illinois pada kelompok putri yang termasuk termasuk pada kriteria baik sampai baik sekali yaitu terdapat 9 orang peserta $(50,00 \%)$ dari 18 orang peserta dikarenakan pada kriteria ini peserta ekstrakurikuler bolabasket memiliki kelincahan gerak yang sangat baik dalam permainan olahraga bolabasket. Tobalina, Calleja-GonzÁlez, De Santos, FernÁndez-López, \& Arteaga-Ayarza (2013) menyatakan bahwa dalam permainan bolabasket unsur kelincahan gerak sangatlah penting terutama dalam gerakan dribble yang selalu digunakan pemain bolabasket saat bermain di lapangan. Sedangkan yang berada dibawah cukup sampai tidak baik berjumlah 9 orang peserta $(50,00 \%)$ dari 18 orang peserta dikarenakan peserta belum mempunyai performa dalam kelincahan gerak. Deprez et al. (2015) menjelaskan bahwa performa kelincahan gerak harus dimiliki oleh seseorang, jika seseorang tidak memiliki performa dalam kelincahan saat berolahraga maka orang tersebut akan mengalami kelelahan.

Sedangkan untuk hasil analisis data dari tes vertical jump pada kelompok $\mathrm{p}$ utri yang termasuk pada kriteria baik sampai baik sekali yaitu terdapat 2 orang peserta $(11,11 \%)$ dari 18 orang peserta, sedangkan yang berada dibawah cukup sampai tidak baik berjumlah 16 orang peserta $(88,89 \%)$ dari 18 orang peserta. Dari paparan dapat disimpulkan bahwa hasil tes vertical jump untuk kelompok putri dikategorikan cukup sampai tidak baik dikarenakan kurangnya latihan untuk daya ledak otot tungkai. Ramírez-Campillo et al. (2016) 
berpendapat bahwa latihan plyometrik dapat meningkatkan daya ledak otot tungkai yang dimiliki oleh seseorang.

Tabel 2. Koefesien Variansi Seluruh Butir Tes Kelompok Putri Peserta Kegiatan Ektrakurikuler Bolabasket di SMAK Santo Albertus Kota Malang

\begin{tabular}{|c|c|c|c|}
\hline No & $\begin{array}{l}\text { Unsur Kondisi } \\
\text { Fisik }\end{array}$ & Jenis Tes & $\mathrm{KV}(\%)$ \\
\hline 1. & Kecepatan Gerak & Lari 20 Meter & 7,98 \\
\hline \multirow{2}{*}{2.} & \multirow{2}{*}{ Kelincahan Gerak } & Tes $T$-Test & 19,40 \\
\hline & & Tes Illinois & 7,86 \\
\hline 3. & Daya Ledak Otot Lengan & $\begin{array}{l}\text { Tes Chest Pass Bola } \\
\text { Medicine }\end{array}$ & 10,73 \\
\hline 4. & Daya Ledak Otot Tungkai & Tes Vertical Jump & 5,68 \\
\hline
\end{tabular}

Berdasarkan koefesien variansi seluruh butir tes kelompok putri peserta kegiatan ekstrakurikuler bolabasket di SMAK Santo Albertus Kota Malang mendapatkan hasil tes vertical jump menunjukan lebih memusat dibandingkan butir tes lainnya, artinya pada tes vertical jump banyak siswa yang mempunyai skor mendekati baik atau sama antar individu. Sedangkan hasil tes kelincahan bentuk $t$-test, koefesien variansi diperoleh $19,40 \%$, berarti butir tes kelincahan gerak bentuk $t$-test lebih menyebar atau beragam yang artinya pada tes tersebut antar individu sangat bervariasi.

Berikut keadaan koefesien variansi seluruh butir tes pada kelompok putri akan disajikan dalam bentuk grafik.

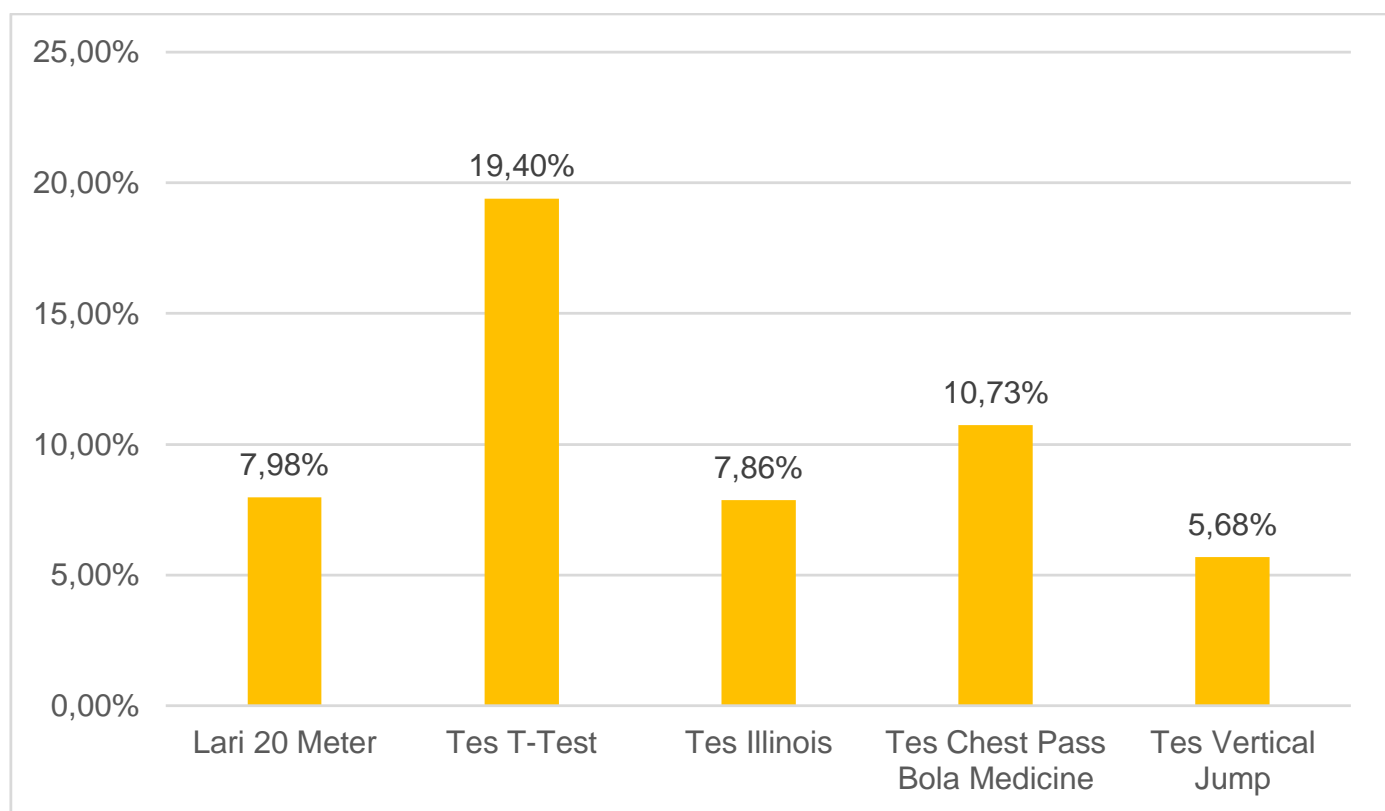

Gambar 2. Grafik Penyebaran Hasil Koefesien Variansi Pada Kelompok Putri Peserta Kegiatan Ekstrakurikuler Bolabasket di SMAK Santo Albertus Kota Malang

Tabel 3. Rangkuman Hasil Koefesien Variansi Dari Peserta Kegiatan Ekstrakurikuler Bolabasket di SMAK Santo Albertus Kota Malang Pada Kelompok Putra dan Putri

\begin{tabular}{llcc}
\hline \multicolumn{1}{c}{ Jenis Kelamin } & \multicolumn{1}{c}{ Jenis Tes } & KV (\%) & Keterangan \\
\hline Putra & Tes Vertical Jump & 5,46 & \multirow{2}{*}{ Memusat } \\
Putri & Tes Vertical Jump & 5,68 & \\
Putra & Tes T-Test & 13,61 & \multirow{2}{*}{ Menyebar } \\
Putri & Tes T-Test & 19,40 & \\
\hline
\end{tabular}


Dengan demikian merujuk pada tabel 3 tentang rangkuman hasil koefesien variansi dari peserta kegiatan ekstrakurikuler bolabasket di SMAK Santo Albertus Kota Malang pada kelompok putra dan putri dapat dikemukakan bahwa diantara kedua kondisi fisik tersebut hasil tes vertical jump pada kelompok putra yaitu sebesar $5,46 \%$ lebih memusat, sedangkan dari kedua kondisi fisik tersebut hasil tes $t$-test pada kelompok putri yaitu sebesar $19,40 \%$ lebih menyebar.

\section{KESIMPULAN}

Kesimpulan hasil tes lari 20 meter, tes $t$-test, tes illinois, tes chest pass bola medicine, tes vertical jump pada kelompok putra, butir tes lari 20 meter dominan pada kriteria menunjukan baik, jenis tes $t$-test dominan kriteria baik, sedangkan tes illinois dominan pada kriteria baik, tes chest pass bola medicine pada kelompok putra dominan pada kriteria cukup, dan tes vertical jump dominan pada kriteria cukup.

Sedangkan hasil tes lari 20 meter, tes $t$-test, tes illinois, tes chest pass bola medicine, tes vertical jump pada kelompok putri, butir tes lari 20 meter dominan pada kriteria menunjukan cukup atau belum baik, jenis tes $t$ test dominan pada kriteria baik, sedangkan tes illinois dominan pada kriteria cukup, tes chest pass bola medicine pada kelompok putri dominan pada kriteria cukup, dan tes vertical jump dominan pada kriteria kurang baik.

\section{Ucapan Terima Kasih}

Keluarga, Stevanus Bambang Irawan dan Veronica Emmy Suyati selaku orang tua kandung, Gregorius Mario Pragita Heksa Hutama dan Benedictus Devdan Danadyaksa selaku saudara kandung, yang selalu memberikan motivasi, semangat, dan doa sehingga peneliti dapat menyelesaikan skripsi ini. Dr. Sapto Adi, M.Kes, selaku Dekan Fakultas IImu Keolahragaan Universitas Negeri Malang yang telah memberikan kesempatan pada peneliti untuk bisa menempuh kuliah di Fakultas IImu Keolahragaan Universitas Negeri Malang. Dr. Lokananta Teguh Hari Wiguno, M.Kes, selaku Ketua Jurusan Pendidikan Jasmani dan Kesehatan Fakultas IImu Keolahragaan Universitas Negeri Malang yang telah memberikan ijin kepada peneliti melakukan proses penelitian. Dr. Siti Nurrochmah, M.Kes, selaku dosen pembimbing I yang telah sabar, tulus ikhlas memberikan bimbingan, masukan, dan motivasi dalam membimbing. Seluruh dosen Fakultas IImu. Keolahragaan jurusan Pendidikan Jasmani dan Kesehatan Universitas Negeri Malang yang telah memberikan pembelajaran dan ilmu yang sangat berharga selama dalam proses perkuliahan. Romo Ignatius Abadi O,Carm selaku Kepala Sekolah SMAK Santo Albertus Kota Malang yang telah memberikan izin untuk melakukan penelitian survei kondisi fisik peserta kegiatan ekstrakurikuler bolabasket sebagai subjek penelitian untuk penulisan skripsi. Yovi Ardivitiyanto, S. Hum selaku pelatih kegiatan ekstrakurikuler bolabasket di SMAK Santo Albertus Kota Malang yang telah membantu dalam penelitian di lapangan. Sahabat-sahabat PJK E' UM 2016, terimakasih atas kritik, saran, bantuan selama proses melakukan penelitian dan pengalaman berharga yang sudah dibagikan sehingga dapat menyelesaikan skripsi ini. Seluruh keluarga besar Fakultas IImu Keolahragaan Universitas Negeri Malang yang telah banyak membantu dalam penyelesaian penulisan skripsi ini. Semoga semua bantuan dan waktu yang sudah diberikan untuk penyelesaian skripsi ini mendapatkan balasan yang lebih besar dari Tuhan yang Maha Esa.

\section{DAFTAR PUSTAKA}

Arhant, C., Wogritsch, R., \& Troxler, J. (2015). Assessment of behavior and physical condition of shelter cats as animal-based indicators of welfare. Journal of Veterinary Behavior: Clinical Applications and Research. https://doi.org/10.1016/j.jveb.2015.03.006

Ariffiansyah, G. (2019). Peningkatan Kemampuan Kelincahan Gerak Akibat Latihan Kelincahan T-Drill Maju dan T-Drill Mundur Terhadap Kelincahan Gerak Olahragawan Karate Dojo Cakrawala Kota Malang. Sport Science and Health, 1(3), 227-232. Retrieved from http://journal2.um.ac.id/index.php/jik/index

Calleja-González, J., Terrados, N., Mielgo-Ayuso, J., Delextrat, A., Jukic, I., Vaquera, A., ... Ostojic, S. M. (2016). Evidence-based post-exercise recovery strategies in basketball. Physician and Sportsmedicine. https://doi.org/10.1080/00913847.2016.1102033 
Capelli, P., Pivetta, C., Esposito, M. S., \& Arber, S. (2017). Locomotor speed control circuits in the caudal brainstem. Nature. https://doi.org/10.1038/nature24064

Chaalali, A., Rouissi, M., Chtara, M., Owen, A., Bragazzi, N. L., Moalla, W., ... Chamari, K. (2016). Agility training in young elite soccer players: Promising results compared to change of direction drills. Biology of Sport. https://doi.org/10.5604/20831862.1217924

Conforto, E. C., Amaral, D. C., da Silva, S. L., Di Felippo, A., \& Kamikawachi, D. S. L. (2016). The agility construct on project management theory. International Journal of Project Management. https://doi.org/10.1016/j.ijproman.2016.01.007

Deprez, D., Valente-Dos-Santos, J., Coelho-E-Silva, M. J., Lenoir, M., Philippaerts, R., \& Vaeyens, R. (2015). Longitudinal Development of Explosive Leg Power from Childhood to Adulthood in Soccer Players. International Journal of Sports Medicine. https://doi.org/10.1055/s-0034-1398577

Finco, M. D., Rocha, R. S., Fão, R. W., \& Santos, F. (2018). Let's Move! International Journal of Game-Based Learning. https://doi.org/10.4018/ijgbl.2018040104

Gołaś, A., Maszczyk, A., Zajac, A., Mikołajec, K., \& Stastny, P. (2016). Optimizing post activation potentiation for explosive activities in competitive sports. Journal of Human Kinetics. https://doi.org/10.1515/hukin2015-0197

Henjilito, R. (2017). Pengaruh Daya Ledak Otot Tungkai, Kecepatan Reaksi dan Motivasi terhadap Kecepatan Lari Jarak Pendek 100 Meter pada Atlet PPLP Provinsi Riau. JOURNAL SPORT AREA. https://doi.org/10.25299/sportarea.2017.vol2(1).595

Horicka, P., Hianik, J., \& Šimonek, J. (2014). The relationship between speed factors and agility in sport games. Journal of Human Sport and Exercise. https://doi.org/10.4100/jhse.2014.91.06

Jamshed, S. (2014). Qualitative research method-interviewing and observation. Journal of Basic and Clinical Pharmacy. https://doi.org/10.4103/0976-0105.141942

Kendzierski, D., \& DeCarlo, K. J. (2016). Physical Activity Enjoyment Scale: Two Validation Studies. Journal of Sport and Exercise Psychology. https://doi.org/10.1123/jsep.13.1.50

Meylan, C. M. P., Cronin, J. B., Oliver, J. L., Hopkins, W. G., \& Contreras, B. (2014). The effect of maturation on adaptations to strength training and detraining in 11-15-year-olds. Scandinavian Journal of Medicine and Science in Sports. https://doi.org/10.1111/sms.12128

Paradisis, G. P., Pappas, P. T., Theodorou, A. S., Zacharogiannis, E. G., Skordilis, E. K., \& Smirniotou, A. S. (2014). Effects of static and dynamic stretching on sprint and jump performance in boys and girls. Journal of Strength and Conditioning Research. https://doi.org/10.1519/JSC.0b013e318295d2fb

Ramírez-Campillo, R., González-Jurado, J. A., Martínez, C., Nakamura, F. Y., Peñailillo, L., Meylan, C. M. P., ... Izquierdo, M. (2016). Effects of plyometric training and creatine supplementation on maximal-intensity exercise and endurance in female soccer players. Journal of Science and Medicine in Sport. https://doi.org/10.1016/j.jsams.2015.10.005

Salvagioni, D. A. J., Melanda, F. N., Mesas, A. E., González, A. D., Gabani, F. L., \& De Andrade, S. M. (2017). Physical, psychological and occupational consequences of job burnout: A systematic review of prospective studies. PLoS ONE. https://doi.org/10.1371/journal.pone.0185781

Sarmento, H., Clemente, F. M., Harper, L. D., Costa, I. T. da, Owen, A., \& Figueiredo, A. J. (2018). Small sided games in soccer-a systematic review. International Journal of Performance Analysis in Sport. https://doi.org/10.1080/24748668.2018.1517288

Smith-Laing, T. (2017). Gender trouble. In Gender Trouble. https://doi.org/10.4324/9781912281718

Tobalina, J. C., Calleja-GonzÁlez, J., De Santos, R. M., FernÁndez-López, J. R., \& Arteaga-Ayarza, A. (2013). The effect of basketball footwear on the vertical ground reaction force during the landing phase of drop jumps. Revista de Psicologia Del Deporte.

Trojian, T. H., Cracco, A., Hall, M., Mascaro, M., Aerni, G., \& Ragle, R. (2013). Basketball injuries: Caring for a basketball team. Current Sports Medicine Reports. 
https://doi.org/10.1097/01.CSMR.0000434055.36042.cd 